\title{
EDITORIAL
}

\section{EDUCAÇÃO DO CAMPO E LETRAMENTOS MÚLTIPLOS}

\author{
Rosana Baptistella \\ Marcus Novaes \\ Luis Gustavo Guimarães \\ Fomos formados no mato - as palavras e eu. \\ O que de terra a palavra se acrescentasse, \\ a gente se acrescentava de terra. \\ O que de água a gente se encharcasse, \\ a palavra se encharcava de água. \\ Porque nós íamos crescendo de em par. \\ Manoel de Barros
}

Falar em esperança, em coletivos, em estarmos juntos, nestes tempos que estamos vivendo, é tão difícil quanto imprescindível. E tem sido nosso mote. Na edição anterior da Linha Mestra - número 41A, especialmente dedicada ao tema da pandemia - terminávamos o editorial com o verbo esperançar, uma clara referência a Paulo Freire. Esta edição, que agora é apresentada ao leitor, vem sendo elaborada, debatida, construída há seis meses, por pessoas do campo da educação, de pensamentos e ações freirianos.

Compõe esta edição o Dossiê "Licenciaturas em Educação do Campo e Letramentos Múltiplos: Formação Docente e Pesquisa", organizado por Mônica Castagna Molina e Rosineide Magalhães de Sousa, ambas Professoras Associadas da Universidade de Brasília (UnB), com ampla publicação nesta área.

As organizadoras selecionaram os artigos, contemplando instituições de diferentes regiões do Brasil que oferecem o curso de Licenciatura em Educação do Campo (LEdoC). São treze artigos de autoria de professores pesquisadores de quatro universidades federais (de Brasília, de Goiás, de Minhas Gerais, de Santa Catarina), uma estadual (de Alagoas), dois institutos federais (do Pará, do Maranhão) e redes municipais e estaduais de regiões diversas, cada qual com sua força e seus desafios próprios.

Os artigos discutem educação, formação docente, cultura, identidade, território. Num discurso contra-hegemônico, abordam o conhecimento e a resistência de ribeirinhos, quilombolas, pescadores, camponeses em sua relação com a terra, com as florestas, com as águas e na luta contra o agronegócio, o veneno, a pecuária extensiva, o latifúndio. Falam de indivíduos e coletivos que, ao mesmo tempo em que se apropriam de saberes científicos, não abandonam seus saberes ancestrais.

Agradecemos às organizadoras do dossiê, aos autores e às autoras dos textos pelo trabalho cuidadoso e em profundidade, assim como ao autor da arte da capa desta edição e da apresentação do dossiê, Gildásio Jardim, artista do Vale do Jequitinhonha que, com maestria, "transvê" a realidade camponesa.

Convidamos nossos leitores a esta imersão na Educação do Campo, tão necessária e com pautas tão urgentes. Boa leitura! 